\title{
Faktor yang Meningkatkan Risiko Terhadap 3 Kategori Kanker Sistem Reproduksi Pada Wanita Usia Subur di Pondok Aren Tangerang Selatan Tahun 2017
}

\author{
Lisnadiyanti $^{1}$ \\ ${ }^{1}$ Universitas Binawan Jakarta Indonesia \\ E-mail: lisnadiyanti39@gmail.com
}

\begin{abstract}
ABSTRAK
Kanker serviks adalah tumor ganas yang tumbuh di dalam leher rahim, yaitu bagi anterendah dari rahim yang menempel pada puncak vagina. Kanker ovarium adalah tumor ganas pada ovarium. Penelitian ini menggunakan metode deskriptif sederhana dengan pendekatan Cross-Sectional. Penelitian dilakukan pada bulan Mei 2017 dengan responden berjumlah 85 orang. Analisa data menggunakan uji proporsi. Hasil penelitian menunjukkan bahwa: 1) pola hubungan usia menarche normal (12-15 tahun) beresiko tinggi sebanyak 42 orang $(49.4 \%), 2)$ pola hubungan faktor yang mempengaruhi usia menarche dengan kategori cukup mempengaruhi beresiko rendah sebanyak 41 orang $(48.2 \%)$, 3) pola hubungan faktor hormonal dengan kategori menstruasi teratur beresiko sedang sebanyak 30 orang $(35.3 \%)$, 4) pola hubungan factor gaya hidup dengan kategori kurang baik beresiko rendahs ebanyak 38 orang $(44.7 \%)$, 5) pola hubungan factor riwayat keluarga dengan kategori tidak memiliki riwayat 3 kategori kanker reproduksi terbesar pada wanita beresiko rendah sebanyak 46 orang (54.1\%), 6) factor risiko terhadap 3 kategori kanker system reproduksi terbesar pada wanita usia subur mayoritas memiliki tingkat risiko rendah sebanyak 49 orang $(57.6 \%)$. Diharapkan masyarakat khususnya wanita usia subur untuk dapat meningkatkan dan memperdulikan kesehatannya terkait kesehatan reproduksi yang dimaksudkan sebagai pencegahan terjadinya 3 kategori kanker reproduksi terbesar pada wanita usia subur.
\end{abstract}

Kata Kunci: Wanita usia subur, kanker, reproduksi wanita

\section{Factors That Increase the Risk of The 3 Major Reproductive Cancer Categories in Women of Childbearing Age in The Pondok Kacang Prima Pondok Aren South Tangerang in 2017}

\begin{abstract}
Women of childbearing age (WUS) are women whose reproductive organs function well between the ages of 2045 years. Breast cancer is a malignant neoplasm disease originating from parenchyma. Cervical cancer is a malignant tumor that grows inside the cervix, which is the lowest part of the uterus attached to the top of the vagina. Ovarian cancer is a malignant tumor in the ovaries. Risk factors in the 3 categories of cancer of the largest female reproductive system have the following equations: age menarche, factors that affect age menarche, hormonal, lifestyle, and family history. This study aims to determine the description of factors that increase the risk of the 3 major reproductive cancer categories in women of childbearing age in the area of PondokKacang Housing Prima PondokArenTangerang Selatan. This research uses simple descriptive method with CrossSectional approach. The study was conducted in May 2017 with respondents amounting to 85 people. Data analysis using proportion test. The results showed that: 1) the pattern of normal menarche age relationship (1215 years) high risk as much as 42 people (49.4\%), 2) the pattern of factor relationships that affect the age of menarche with low enough affect category low risk as much as 41 people $(48.2 \%)$, 3) pattern of hormonal factor correlation with regular menstruation category at medium risk as many as 30 people (35.3\%), 4) low lifestyle lifestyle association pattern with low risk of 38 people (44.7\%), 5) family history factor correlation pattern Category has no history of 3 major reproductive cancer categories in low risk women as many as 46 people (54.1\%), 6) risk factors for the 3 major reproductive cancer categories in women of childbearing age majority having low risk level as many as 49 people (57.6\%). It is expected that the community especially women of childbearing age to be able to improve and care about health related reproductive health that is intended as prevention of the 3 major reproductive cancer categories in women of childbearing age.
\end{abstract}

Keywords: Women of childbearing age, breast cancer, cervical cancer, ovarian cancer, menarche age, factors affecting menarche, hormonal, lifestyle, family history 


\section{Pendahuluan}

Wanita mempunyai peranan sentral dalam menentukan kualitas generasi penerus dan kualitas keluarga. Wanita yang sehat mempunyai kesempatan untuk memenuhi semua potensi yang ada dalam dirinya. Disamping itu, ia akan mempunyai bayi yang sehat, mampu merawat keluarga dengan lebih baik, mendidik anakanaknya.(Arsenijevic et al., 2012; Ferlay et al., 2015; K. et al., 2010; Sanajaoba Singh N, Sharat Singh N, , Narendra RK, 2010) Sistem reproduksi wanita dirancang untuk dapat melaksanakan beberapa fungsi, Rancangan tersebut sangat sempurna sehingga memungkinkan sebuah kehidupan baru terbentuk secara normal. Sistem reproduksi wanita dan bagian-bagiannya terdiri atas vagina dan leher Rahim berfungsi sebagai tempat masuknya sperma untuk mencari dan membuahi sel telur. Ovarium menghasilkan sel telur dan hormon. Saluran tuba menyediakan tempat untuk terjadinya pembuahan dan pertumbuhan embrio di minggu pertama. Rahim adalah tempat embrio tertanam selama Sembilan bulan pertumbuhan janin. Dan payudara berfungsi untuk memberi nutrisi dan antibody bagi bayi yang baru lahir. (Bray et al., 2018; DeSantis, Ma, Bryan, \& Jemal, 2014; Marcom, 2017)

$$
\text { Berbagai gangguan yang }
$$

mengancam kesehatan reproduksi bias juga disebabkan oleh perilaku dan kebiasaan yang buruk. gangguan reproduksi bias dimulai dari infeksi bagian luar hingga kebagian dalam atau karena kebiasaan yang kurang sehat menjadikan masalah yang membuat system reproduksi menjadi terganggu. (Curry et al., 2018; Ndikom \& Ofi, 2012; Society, 2014; Sudenga, Rositch, Otieno, \& Smith, 2013). Beberapa gangguan kesehatan reproduksi wanita ialah siklus menstruasi tidak teratur, gangguan endometriosis, kanker pada system reproduksi dan infeksi pada bagian vagina. (Hsieh, Trichopoulos, Katsouyanni, \& Yuasa, 1990; Marmot et al., 2013; Zermeño-Nava et al., 2018)
Di Amerika Serikat, antara 1975 dan 1994, angka kasus kanker pada wanita berusia kurang dari 45 tahun meningkat 1,6 persen per tahun. Saat ini penyakit tidak menular, termasuk kanker menjadi masalah kesehatan utama di dunia maupun di Indonesia. Menurut data WHO tahun 2013, insidens kanker meningkat dari 12,7 juta kasus tahun 2008 menjadi 14,1 juta kasus pada tahun 2012. Sedangkan jumlah kematian meningkat dari 7,6 juta orang tahun 2008 menjadi 8,2 juta pada tahun 2012. Kanker menjadi penyebab kematian nomor 2 di dunia sebesar $13 \%$ setelah penyakit kardiovaskular. Diperkirakan padat ahun 2030 insidens kanker dapat mencapai 26 juta dan 17 juta diantaranya meninggal akibat kanker, terlebih untuk Negara miskin dan berkembang kejadiannya akan lebih cepat. Di Indonesia, prevalensi penyakit kanker juga cukup tinggi. (Batubara, Soesanti, \& van de Waal, 2010; D'Aloisio, Deroo, Baird, Weinberg, \& Sandler, 2013; Elks et al., 2010; Perry et al., 2014)

Berdasarkan data Riset Kesehatan Dasar (Riskesdas) tahun 2013, prevalensi tumor/kanker di Indonesia adalah 1,4 per penduduk, atau sekitar 330.000 orang. Kanker tertinggi di Indonesia pada perempuan adalah kanker payudara dan kanker leher rahim. Berdasarkan estimasi Globocan, International Agency for Research on Cancer (IARC) tahun 2012, insidens kanker payudara sebesar 40 per 100.000 perempuan, kanker leher rahim 17 per 100.000 perempuan. Berdasarkan data Sistem Informasi Rumah Sakit 2010, kasus rawat inap kanker payudara 12.014 kasus (28,7\%), kanker leher rahim 5.349 kasus $(12,8 \%)$. Berdasarkan data Rumah Sakit Kanker Dharmais 10 besar kanker kasus baru tahun 2014 yaitu kanker payudara 1290 kasus, kanker serviks 219 kasus, kanker paru 205 kasus, KNF (KarsinomaNasofaring) 201 kasus, kanker rektum 192 kasus, kanker thyroid 175 kasus, kanker ovarium 145 kasus, hepatoma 114 kasus, dan LNH (Limfoma NonHodgkin) 114 kasus. Berdasarkan data dari 
Rumah Sakit Kanker Dharmais pada kanker reproduksi pada wanita terdapat 3 jenis kanker terbesar yaitu kanker payudara, kanker serviks dan kanker ovarium. Berdasarkan uraian diatas, penulis menganggap perlu dilakukan penelitian tentang "Gambaran Faktor-Faktor yang Meningkatkan Risiko Terhadap 3 Kategori Kanker Sistem Reproduksi Terbesar Pada Wanita Usia Subur di Wilayah Perumahan Pondok Kacang Prima Pondok Aren Tangerang Selatan".

\section{Metode Penelitian}

Desain penelitian ini adalah deskriptif sederhana yaitu keadaan yang ingin dijelaskan bukan berasal dari satu populasi tanpa menghubungkannya dengan keadaan lain yang juga ditemukan pada populasi tersebut. Deskriptif yaitu suatu metode penelitian yang dilakukan untuk mendeskriptifkan atau menggambarkan fenomena yang terjadi di dalam masyarakat. Jenis rancangan menggunakan metode survey dengan pendekatan CrossSectional (Notoatmodjo, 2010). Pengambilan data yang dilakukan dalam satu kurun waktu, maksimal dua atau tiga bulan. Peneliti mengumpulkan data dari sampel pada waktu yang bersamaan. Penelitian ini menggunakan desain crosssectional karena prevalensi masalah yang terjadi cukup besar, sehingga lebih cocok menggunakan studi cross-sectional dari pada case control. Dalam penelitian ini pengambilan responden atau penentuan responden dilakukan secara sampling dimana teknik pengambilan sampel adalah Simple Random Sampling dengan sampel sebanyak 85 orang. Pada penelitian ini memiliki kriteria inklusi yaitu semua wanita usia subur dengan usia minimal 20 tahun dan usia maksimal 45 tahun yang bersedia untuk di wawancara dan dijadikan sampel. Data yang digunakan dalam penelitian ini adalah data primer dan data skunder, sementara untuk instrumen yang digunakan adalah menggunakan skala likert.

\section{Hasil Penelitian}

Tabel 1 Distribusi Responden Berdasarkan Faktor Risiko Terhadap 3 Kategori Kanker Sistem Reproduksi Terbesar Pada Wanita Usia Subur

\begin{tabular}{|c|c|c|}
\hline Tingkat Risiko & Frekuensi & Presentase (\%) \\
\hline Risiko Rendah & 49 & $57.6 \%$ \\
\hline Risiko Sedang & 35 & $41.2 \%$ \\
\hline Risiko Tinggi & 1 & $1.2 \%$ \\
\hline Total & $\mathbf{8 5}$ & $\mathbf{1 0 0 . 0 \%}$ \\
\hline
\end{tabular}

Tabel 2 Distribusi Responden Berdasarkan Usia Menarche

\begin{tabular}{|c|c|c|}
\hline Usia menarche & Frekuensi & Presentase (\%) \\
\hline Cepat $(<12$ tahun) & 3 & $3.5 \%$ \\
\hline Normal $(12-15$ tahun) & 80 & $94.1 \%$ \\
\hline Lambat $(>15$ tahun) & 2 & $2.4 \%$ \\
\hline Total & $\mathbf{8 5}$ & $\mathbf{1 0 0 . 0 \%}$ \\
\hline
\end{tabular}

Tabel 3 Distribusi Responden Berdasarkan Pola Hubungan Usia Menarche Dengan Faktor Risiko 3 Kategori Kanker Sistem Reproduksi Pada Wanita Usia Subur

\begin{tabular}{|c|c|c|c|c|}
\hline \multirow{2}{*}{ Usia Menarche } & \multicolumn{3}{|c|}{$\begin{array}{c}\text { FaktorRisiko } 3 \text { Kategori Kanker Sistem Reproduksi } \\
\text { Terbesar Pada Wanita Usia Subur }\end{array}$} & \multirow{2}{*}{ Total } \\
\hline & $\begin{array}{l}\text { Risiko } \\
\text { Rendah }\end{array}$ & Risiko Sedang & Risiko Tinggi & \\
\hline
\end{tabular}




\begin{tabular}{|c|c|c|c|c|c|c|c|c|}
\hline & $\mathrm{F}$ & $\%$ & $\mathrm{~F}$ & $\%$ & $\mathrm{~F}$ & $\%$ & $\mathrm{~F}$ & $\%$ \\
\hline $\begin{array}{c}\text { Cepat } \\
(<12 \text { tahun })\end{array}$ & 0 & $0.0 \%$ & 1 & $1.2 \%$ & 2 & $2.4 \%$ & 3 & $3.5 \%$ \\
\hline $\begin{array}{c}\text { Normal } \\
(12-15 \text { tahun })\end{array}$ & 2 & $2.4 \%$ & 36 & $42.4 \%$ & 42 & $49.4 \%$ & 80 & $94.1 \%$ \\
\hline $\begin{array}{c}\text { Lambat } \\
(>15 \text { tahun })\end{array}$ & 0 & $0.0 \%$ & 1 & $1.2 \%$ & 1 & $1.2 \%$ & 2 & $2.4 \%$ \\
\hline Total & 2 & $2.4 \%$ & 38 & $44.7 \%$ & 45 & $52.9 \%$ & 85 & $100.0 \%$ \\
\hline
\end{tabular}

Tabel 4 Distribusi Responden Berdasarkan Faktor yang Mempengaruhi Usia Menarche

\begin{tabular}{|c|c|c|}
\hline $\begin{array}{c}\text { Faktor Yang Mempengaruhi Usia } \\
\text { Menarche }\end{array}$ & Frekuensi & Presentase (\%) \\
\hline Sangat Mempengaruhi & 5 & $5.9 \%$ \\
\hline Cukup Mempengaruhi & 72 & $84.7 \%$ \\
\hline Kurang Mempengaruhi & 8 & $9.4 \%$ \\
\hline Total & 85 & $100.0 \%$ \\
\hline
\end{tabular}

Tabel 5 Distribusi Responden Berdasarkan Pola Hubungan Faktor Yang Mempengaruhi Menarche Dengan Faktor Risiko 3 Kategori Kanker Sistem Reproduksi Terbesar Pada Wanita Usia Subur

\begin{tabular}{|c|c|c|c|c|c|c|c|c|}
\hline \multirow{3}{*}{$\begin{array}{l}\text { Faktor Yang } \\
\text { Mempengaruhi } \\
\text { Menarche }\end{array}$} & \multicolumn{6}{|c|}{$\begin{array}{c}\text { Faktor Risiko } 3 \text { Kategori Kanker Sistem } \\
\text { Reproduksi Terbesar Pada Wanita Usia } \\
\text { Subur }\end{array}$} & & \multirow{2}{*}{ Total } \\
\hline & \multicolumn{2}{|c|}{$\begin{array}{l}\text { Risiko } \\
\text { Rendah }\end{array}$} & \multicolumn{2}{|c|}{$\begin{array}{l}\text { Risiko } \\
\text { Sedang }\end{array}$} & \multicolumn{2}{|c|}{$\begin{array}{l}\text { Risiko } \\
\text { Tinggi }\end{array}$} & & \\
\hline & $\mathrm{F}$ & $\%$ & $\mathrm{~F}$ & $\%$ & $\mathrm{~F}$ & $\%$ & $\mathrm{~F}$ & $\%$ \\
\hline $\begin{array}{c}\text { Sangat } \\
\text { Mempengaruhi }\end{array}$ & 0 & $0.0 \%$ & 4 & $4.7 \%$ & 1 & $1.2 \%$ & 5 & $5.9 \%$ \\
\hline $\begin{array}{c}\text { Cukup } \\
\text { Mempengaruhi }\end{array}$ & 41 & $48.2 \%$ & 31 & $36.5 \%$ & 0 & $0.0 \%$ & 72 & $84.7 \%$ \\
\hline $\begin{array}{c}\text { Kurang } \\
\text { Mempengaruhi }\end{array}$ & 8 & $9.4 \%$ & 0 & $0.0 \%$ & 0 & $0.0 \%$ & 8 & $9.4 \%$ \\
\hline Total & 49 & $57.6 \%$ & 35 & $41.2 \%$ & 1 & $1.2 \%$ & 85 & $100.0 \%$ \\
\hline
\end{tabular}

Tabel 6 Disribusi Responden Berdasarkan Hormonal

\begin{tabular}{|c|c|c|}
\hline Hormonal & Frekuensi & Presentase (\%) \\
\hline Menstruasi Teratur & 41 & $48.2 \%$ \\
\hline Menstruasi Tidak Teratur & 31 & $36.5 \%$ \\
\hline Menstruasi Berlebihan & 13 & $15.3 \%$ \\
\hline Total & 85 & $100.0 \%$ \\
\hline
\end{tabular}

Tabel 7 Distribusi Responden Berdasarkan Pola Hubungan Hormonal Dengan Faktor Risiko 3 Kategori Kanker Sistem Reproduksi Terbesar Pada Wanita USia Subur

\begin{tabular}{|c|c|c|c|c|c|c|c|c|}
\hline \multirow{3}{*}{ Hormonal } & \multicolumn{5}{|c|}{$\begin{array}{c}\text { Faktor Risiko 3 Kategori Kanker Sistem } \\
\text { Reproduksi Terbesar Pada Wanita Usia Subur }\end{array}$} & \multicolumn{2}{|c|}{\multirow{2}{*}{ Total }} \\
\cline { 2 - 8 } & Risiko Rendah & Risiko Sedang & Risiko Tinggi & \multicolumn{2}{|c|}{} \\
\hline & F & $\%$ & F & $\%$ & F & $\%$ & F & $\%$ \\
\hline
\end{tabular}




\begin{tabular}{|c|c|c|c|c|c|c|c|c|}
\hline Menstruasi Teratur & 10 & $11.8 \%$ & 30 & $35.3 \%$ & 1 & $1.2 \%$ & 41 & $48.2 \%$ \\
\hline $\begin{array}{c}\text { Menstruasi Tidak } \\
\text { Teratur }\end{array}$ & 26 & $30.6 \%$ & 5 & $5.9 \%$ & 0 & $0.0 \%$ & 31 & $36.5 \%$ \\
\hline $\begin{array}{c}\text { Menstruasi } \\
\text { Berlebihan }\end{array}$ & 13 & $15.3 \%$ & 0 & $0.0 \%$ & 0 & $0.0 \%$ & 13 & $15.3 \%$ \\
\hline Total & 49 & $57.6 \%$ & 35 & $41.2 \%$ & 1 & $1.2 \%$ & 85 & $100.0 \%$ \\
\hline
\end{tabular}

Tabel 8 Distribusi Responden Berdasarkan Gaya Hidup

\begin{tabular}{|c|c|c|}
\hline Gaya Hidup & Frekuensi & Presentase (\%) \\
\hline Sangat Baik & 2 & $2.4 \%$ \\
\hline Cukup Baik & 38 & $44.7 \%$ \\
\hline Kurang Baik & 45 & $52.9 \%$ \\
\hline Total & 85 & $100.0 \%$ \\
\hline
\end{tabular}

Tabel 9 Distribusi Responden Berdasarkan Pola Hubungan Gaya Hidup Dengan Faktor Risiko 3 Kategori Kanker Sistem Reprosduksi Terbesar Pada Wanita Usia Subur

\begin{tabular}{|c|c|c|c|c|c|c|c|c|}
\hline \multirow{2}{*}{ Gaya Hidup } & \multicolumn{6}{|c|}{ Faktor Risiko 3 Kategori Kanker Sistem } & \multicolumn{3}{|c|}{ Total } \\
\cline { 2 - 8 } & Reproduksi Terbesar Pada Wanita Usia Subur & \multicolumn{2}{|c|}{ Tota Rendah } & Risiko Sedang & Risiko Tinggi & \multicolumn{2}{c|}{} \\
\hline & $\mathrm{F}$ & $\%$ & $\mathrm{~F}$ & $\%$ & $\mathrm{~F}$ & $\%$ & $\mathrm{~F}$ & $\%$ \\
\hline Sangat Baik & 0 & $0.0 \%$ & 1 & $1.2 \%$ & 1 & $1.2 \%$ & 2 & $2.4 \%$ \\
\hline Cukup Baik & 11 & $12.9 \%$ & 27 & $31.8 \%$ & 0 & $0.0 \%$ & 38 & $44.7 \%$ \\
\hline Kurang Baik & 38 & $44.7 \%$ & 7 & $8.2 \%$ & 0 & $0.0 \%$ & 45 & $52.9 \%$ \\
\hline Total & 49 & $57.6 \%$ & 35 & $41.2 \%$ & 1 & $1.2 \%$ & 85 & $100.0 \%$ \\
\hline
\end{tabular}

Tabel 10 Distribusi Responden Berdasarkan Riwayat Keluarga

\begin{tabular}{|c|c|c|c|c|c|c|c|c|}
\hline \multirow{3}{*}{ Riwayat Keluarga } & \multicolumn{6}{|c|}{$\begin{array}{l}\text { Faktor Risiko } 3 \text { Kategori Kanker Sistem Reproduksi Pada Wanita Usia } \\
\text { Subur }\end{array}$} & \multirow{2}{*}{\multicolumn{2}{|c|}{ Total }} \\
\hline & \multicolumn{2}{|c|}{ Risiko Rendah } & \multicolumn{2}{|c|}{ Risiko Sedang } & \multicolumn{2}{|c|}{ Risiko Tinggi } & & \\
\hline & $\mathrm{F}$ & $\%$ & $\mathrm{~F}$ & $\%$ & $\mathrm{~F}$ & $\%$ & $\mathrm{~F}$ & $\%$ \\
\hline $\begin{array}{c}\text { Tidak Memiliki Riwayat } \\
3 \text { Kategori Kanker } \\
\text { Reproduksi Terbesar } \\
\text { Pada Wanita }\end{array}$ & 46 & $54.1 \%$ & 25 & $29.4 \%$ & 0 & $0.0 \%$ & 71 & $83.5 \%$ \\
\hline $\begin{array}{c}\text { Memiliki Salah Satu } \\
\text { Riwayat Dari } 3 \text { Kategori } \\
\text { Kanker Reproduksi } \\
\text { Terbesar Pada Wanita }\end{array}$ & 3 & $3.5 \%$ & 9 & $10.6 \%$ & 0 & $0.0 \%$ & 12 & $14.1 \%$ \\
\hline $\begin{array}{c}\text { Memiliki Riwayat } 3 \\
\text { Kategori Kanker } \\
\text { Reproduksi Terbesar } \\
\text { Pada Wanita }\end{array}$ & 0 & $0.0 \%$ & 1 & $1.2 \%$ & 1 & $1.2 \%$ & 2 & $2.4 \%$ \\
\hline Total & 49 & $57.6 \%$ & 35 & $41.2 \%$ & 1 & $1.2 \%$ & 85 & $100.0 \%$ \\
\hline
\end{tabular}


Tabel 11 Distribusi Responden Berdasarkan Pola Hubungan Riwayat Keluarga Terhadap Faktor Risiko 3 Kategori Kanker Sistem Reproduksi Terbesar Pada Wanita Usia Subur.

\begin{tabular}{|c|c|c|}
\hline Riwayat keluarga & Frekuensi & $\begin{array}{l}\text { Presentase } \\
(\%)\end{array}$ \\
\hline $\begin{array}{c}\text { Tidak Memiliki Riwayat } 3 \text { Kategori Kanker Terbesar Pada Reproduksi } \\
\text { Wanita }\end{array}$ & 71 & $83.5 \%$ \\
\hline $\begin{array}{c}\text { Memiliki Salah Satu Riwayat Dari } 3 \text { Kategori Kanker Terbesar Pada } \\
\text { Reproduksi Wanita }\end{array}$ & 12 & $14.1 \%$ \\
\hline $\begin{array}{l}\text { Memiliki Riwayat } 3 \text { Kategori Kanker Terbesar Pada Reproduksi } \\
\text { Wanita }\end{array}$ & 2 & $2.4 \%$ \\
\hline Total & 85 & $100.0 \%$ \\
\hline
\end{tabular}

\section{Pembahasan}

\section{Analisa Univariat}

Hasil penelitian terhadap 85 orang responden yang merupakan wanita usia subur di Perumahan Pondok Kacang Prima Pondok Aren Tangerang Selatan, diperoleh responden yang memiliki risiko terhadap 3 kategori kanker sistem reproduksi pada wanita usia subur dengan tingkat risiko rendah sebanyak 49 orang (57.6\%), dengan tingkat risiko sedang sebanyak 35 orang $(41.2 \%)$, dan sisanya dengan tingkat risiko tinggi sebanyak 1 orang (1.2\%). Dalam penelitian ini usia menarche mayoritas responden adalah yang memiliki tingkat risiko rendah.

Hasil penelitian diperoleh responden yang mengalami usia menarche normal yaitu saat berusia 12-15 tahun sebanyak 80 orang $(94.1 \%)$, usia menarche yang cepat yaitu saat berusia $<12$ tahun sebanyak 3 orang $(3.5 \%)$, dan sisanya usia menarche yang lambat yaitu berusia $>15$ tahun sebanyak 2 orang (2.4\%). Dalam penelitian ini usia menarche mayoritas responden adalah normal yang dimana berusia $12-15$ tahun.

Dari hasil pola hubungan pada faktor usia menarche dengan faktor risiko 3 kategori kanker sistem reproduksi terbesar pada wanita usia subur mayoritas responden pada kategori cepat sebanyak 2 orang dengan presentase $2.4 \%$ dimana berada pada kategori risiko tinggi, pada kategori normal mayoritas responden sebanyak 42 orang dengan presentase $49.4 \%$ berada pada kategori risiko tinggi, dan pada kategori lambat menunjukkan frekuensi yang sama pada risiko sedang dan risiko tinggi yaitu sebanyak 1 orang dengan presentase $1.2 \%$.

Dari hasil jurnal penelitian yang ditulis oleh Fachlevy, Abdullah, dan Russeng dengan judul "Faktor Risiko Kanker Ovarium di RSUP Wahidin Sudirohusodo Makassar" pada tahun 2011 meneliti mengenai faktor risiko terjadinya kanker ovarium yang diantaranya ialah usia menarche, paritas, riwayat keluarga, penggunaan bedak, dan indeks massa tubuh. Dari hasil penelitian tersebut didapatkan bahwa usia menarche didapatkan nilai OR sebesar 2,054 pada tingkat kepercayaan $(\mathrm{CI})=95 \%$ dengan lower limit $=1,061$ dan upper limit $=4,174$, karena nilai lower limit dan upper limit tidak mencakup nilai satu, maka nilai 2,104 dianggap bermakna antara usia menarche dengan kejadian kanker ovarium.

Dari data diatas, peneliti menyimpulkan terdapat kesenjangan dari hasil temuan peneliti yang telah dilakukan di Wilayah Perumahan Pondok Kacang Prima Pondok Aren Tangerang Selatan tahun 2017 dengan beberapa temuan dari hasil penelitian terkait, yang dimana penelitian terkait mengungkapkan bahwa usia menarche cepat ( $<12$ tahun) merupakan risiko tinggi terjadinya 3 kategori kanker reproduksi terbesar pada wanita usia subur, sedangkan hasil temuan peneliti usia menarche normal (12-15 
tahun) beresiko tinggi terjadinya 3 kategori kanker reproduksi terbesar pada wanita usia subur.

Hasil penelitian diperoleh responden yang memiliki frekuensi faktor yang mempengaruhi menarche dengan kategori cukup mempengaruhi sebanyak 72 orang dengan presentase $84.7 \%$, pada kategori kurang mempengaruhi sebanyak 8 orang dengan presentase $9.4 \%$, dan sisanya pada kategori sangat mempengaruhi sebanyak 5 orang dengan presentase $5.9 \%$. Dalam penelitian ini faktor yang mempengaruhi usia menarche mayoritas responden adalah pada kategori cukup mempengaruhi. (Horvath, Chilo, \& Lindblad, 2010) (Arsenijevic et al., 2012; Carwile et al., 2015; ICO \& Centre, 2014)

Menurut (Lestari, 2011) faktor yang mempengaruhi usia menarche ada dua, yaitu dari segi faktor internal dimana diantaranya ialah organ reproduksi, hormonal, dan penyakit; dan dari segi faktor eksternal yakni gizi, pengetahuan orang tua, dan gaya hidup. Menurut Musruroh, 2014 bahwa faktor yang dapat mempengaruhi usia menarche diantaranya ialah faktor lingkungan, genetik, sosial ekonomi dan budaya, serta peran orang tua. Peran orang tua sangat besar dalam mempengaruhi usia menarche anak, misal saja ibu, dengan semakin tingginya pendidikan ibu dan usia menarche yang dialami oleh si ibu mampu memprediksi usia menarche putrinya. Apabila peran orang tua terutama si ibu kurang dalam memberikan pengetahuan tentang menstruasi dan perubahanperubahan yang akan terjadi pada fisik si anak juga akan berdampak pada kondisi psikologis si anak.(Editor, 2016; Getahun, Mazengia, Abuhay, \& Birhanu, 2013; Insanu, Anggadiredja, \& Kayser, 2012)

Sedangkan menurut (Herawati, 2013) didapatkan bahwa dari analisis statistik uji T Independen diperoleh nilai pvalue $=0,009$, yang berarti ada hubungan yang signifikan antara usia menarche responden dengan perilaku kebiasaan berolahraga pada saat sebelum menarche, yaitu lebih cepat menarche dibandingkan dengan tidak melakukan olahraga $(12,07$ tahun). Dari hasil penelitian terkait diatas yang mempengaruhi usia menarche adalah olahraga, tetapi olahraga bukan satusatunya faktor yang mempengaruhi usia menarche. Penyebab faktor yang mempengaruhi usia menarche tidak hanya dipengaruhi oleh faktor tunggal, selalu ada konstribusi dari berbagai aspek, seperti pada teori terkait diatas yang telah dijelaskan salah satunya menurut Lestari, 2011 beberapa faktornya ialah faktor internal dimana diantaranya yakni organ reproduksi, hormonal, dan penyakit; dan dari segi faktor eksternal yakni gizi, pengetahuan orang tua, dan gaya hidup.

Dari hasil pola hubungan pada faktor yang mempengaruhi usia menarche dengan faktor risiko 3 kategori kanker sistem reproduksi terbesar pada wanita usia subur mayoritas responden pada kategori sangat mempengaruhi sebanyak 4 orang dengan presentase $4.7 \%$ dimana berada pada kategori risiko sedang, pada kategori cukup mempengaruhi mayoritas responden sebanyak 41 orang dengan presentase $48.2 \%$ berada pada kategori risiko rendah, dan pada kategori kurang mempengaruhi mayoritas responden sebanyak 8 orang dengan presentase $9.4 \%$ berada pada risiko rendah.

Hasil penelitian diperoleh responden yang memiliki frekuensi faktor hormonal dengan kategori menstruasi teratur sebanyak 41 orang dengan presentase $48.2 \%$, pada kategori menstruasi tidak teratur sebanyak 31 orang dengan presentase $36.5 \%$, dan sisanya pada kategori menstruasi berlebihan sebanyak 13 orang dengan presentase $15.3 \%$. Dalam penelitian ini faktor hormonal mayoritas responden adalah pada kategori menstruasi teratur.

Dengan demikian, peneliti menyimpulkan terdapat kesenjangan dari hasil temuan peneliti yang telah dilakukan di Wilayah Perumahan Pondok Kacang Prima Pondok Aren Tangerang Selatan tahun 2017 dengan beberapa temuan dari hasil teori dan penelitian terkait yang 
dimana mengungkapkan bahwa gangguan menstruasi yakni menstruasi tidak teratur merupakan risiko tinggi terjadinya 3 kategori kanker reproduksi terbesar pada wanita usia subur, sedangkan hasil temuan peneliti pada kategori menstruasi tidak teratur berada pada kategori risiko rendah terjadinya 3 kategori kanker reproduksi terbesar pada wanita usia subur.

Hasil penelitian diperoleh, responden yang memiliki frekuensi faktor gaya hidup dengan kategori kurang baik sebanyak 45 orang dengan presentase $52.9 \%$, pada kategori cukup baik sebanyak 38 orang dengan presentase $44,7 \%$, dan sisanya pada kategori sangat baik sebanyak 2 orang dengan presentase $2.4 \%$. Dalam penelitian ini faktor gaya hidup mayoritas responden adalah pada kategori kurang baik.

Dari data diatas, peneliti menyimpulkan terdapat kesenjangan dari hasil temuan peneliti yang telah dilakukan di Wilayah Perumahan Pondok Kacang Prima Pondok Aren Tangerang Selatan tahun 2017 dengan beberapa temuan dari hasil teori dan penelitian terkait yang dimana mengungkapkan bahwa faktor gaya hidup yang kurang baik merupakan risiko tinggi terjadinya 3 kategori kanker reproduksi terbesar pada wanita usia subur, sedangkan hasil temuan peneliti pada kategori gaya hidup kurang baik berada pada kategori risiko rendah terjadinya 3 kategori kanker reproduksi terbesar pada wanita usia subur.

Hasil penelitian doperoleh, responden yang memiliki frekuensi faktor riwayat keluarga dengan kategori tidak memiliki riwayat 3 kategori kanker terbesar pada wanita sebanyak 71 orang dengan presentase $83.5 \%$, pada kategori memiliki salah satu riwayat dari 3 kategori kanker terbesar pada reproduksi wanita sebanyak 12 orang dengan presentase $14.1 \%$, dan sisanya pada kategori memiliki riwayat 3 kategori kanker terbesar pada reproduksi wanita sebanyak 2 orang dengan presentase $2.4 \%$. Dalam penelitian ini faktor riwayat keluarga mayoritas responden adalah tidak memiliki riwayat 3 kategori kanker terbesar pada wanita.

Dari data diatas, peneliti menyimpulkan terdapat persamaan dari hasil temuan peneliti yang telah dilakukan di Wilayah Perumahan Pondok Kacang Prima Pondok Aren Tangerang Selatan tahun 2017 dengan beberapa temuan dari hasil penelitian terkait yang dimana mengungkapkan bahwa faktor riwayat keluarga yang memiliki riwayat salah satu maupun ketiga kategori kanker terbesar pada wanita merupakan risiko tinggi terjadinya 3 kategori kanker reproduksi terbesar pada wanita usia subur.

\section{Kesimpulan}

Hasil Penelitian memperlihatkan bahwa pola hubungan pada temuan peneliti yang telah dilakukan di Wilayah Perumahan Pondok Kacang Prima Pondok Aren Tangerang Selatan usia menarche normal (12-15 tahun) beresiko tinggi terjadinya 3 kategori kanker reproduksi terbesar pada wanita usia subur sebanyak 42 orang $(49.4 \%)$. Faktor yang mempengaruhi usia menarche dengan kategori cukup mempengaruhi beresiko rendah terjadinya 3 kategori kanker reproduksi terbesar pada wanita usia subur sebanyak 41 orang $(48.2 \%)$. Faktor hormonal dengan kategori menstruasi teratur beresiko sedang terjadinya 3 kategori kanker reproduksi terbesar pada wanita usia subur sebanyak 30 orang (35.3\%). Faktor gaya hidup dengan kategori kurang baik beresiko rendah terjadinya 3 kategori kanker reproduksi terbesar pada wanita usia subur sebanyak 38 orang $(44.7 \%)$. Faktor riwayat keluarga dengan kategori tidak memiliki riwayat 3 kategori kanker reproduksi terbesar pada wanita beresiko rendah terjadinya 3 kategori kanker reproduksi terbesar pada wanita usia subur sebanyak 46 orang (54.1\%). Mayoritas memiliki tingkat risiko rendah terjadinya 3 kategori kanker reproduksi terbesar pada wanita usia subur sebanyak 49 orang $(57.6 \%)$. 
Penelitian ini dapat dijadikan sebagai dasar penelitian lebih lanjut yang berkaitan dengan ilmu keperawatan maternitas dan ilmu kebidanan mengenai gambaran faktor-faktor yang meningkatkan risiko terhadap 3 kategori kanker sistem reproduksi terbesar pada wanita usia subur. Peneliti menyadari keterbatasan yang dialami seperti kurangnya sumber referensi dari penelitian terkait yang dimana peneliti mencari satu persatu dari 3 kategori kanker reproduksi terbesar pada wanita usia subur lalu kemudian dibuat kesimpulan dari ketiga masalah tersebut, maka dari itu untuk penelitian selanjutnya untuk meneruskan penelitian ini diantaranya menganalisa hubungan mengenai faktor yang mempengaruhi usia menarche dan faktor hormonal yang dimana membahas siklus menstruasi terhadap risiko terjadinya 3 kategori kanker reproduksi terbesar pada wanita usia subur. Adanya penelitian ini, diharapkan masyarakat khususnya wanita usia subur untuk dapat meningkatkan dan memperdulikan kesehatannya terkait kesehatan reproduksi yang dimaksudkan sebagai pencegahan terjadinya 3 kategori kanker reproduksi terbesar pada wanita usia subur, dan diharapkan agar informasi ini dapat dijadikan pendidikan kesehatan untuk keluarga dan kerabat. Pada pelayanan kesehatan diharapkan penelitian ini dapat digunakan untuk mempersiapkan program pendidikan kesehatan yang terintegrasi tentang pencegahan dan deteksi dini terhadap faktor-faktor yang dapat meningkatkan risiko pada 3 kategori kanker reproduksi terbesar pada wanita usia subur.

\section{Referensi}

Arsenijevic, M., Milovanovic, M., Volarevic, V., Canovic, D., Arsenijevic, N., Soldatovic, T., ... Bugarcic, Z. D. (2012). Cytotoxic properties of platinum(IV) and dinuclear platinum(II) complexes and their ligand substitution reactions with guanosine50-monophosphate. Transition Metal Chemistry. https://doi.org/10.1007/s11243-0129613-4

Batubara, J. R. L., Soesanti, F., \& van de Waal, H. D. (2010). Age at menarche in indonesian girls: a national survey. Acta Medica Indonesiana.

Bray, F., Ferlay, J., Soerjomataram, I., Siegel, R. L., Torre, L. A., \& Jemal, A. (2018). Global cancer statistics 2018: GLOBOCAN estimates of incidence and mortality worldwide for 36 cancers in 185 countries. CA: $A$ Cancer Journal for Clinicians. https://doi.org/10.3322/caac.21492

Carwile, J. L., CWillett, W., Spiegelman, D., Hertzmark, E., Rich-Edwards, J., Frazier, A. L., \& Michels, K. B. (2015). Sugar-sweetened beverage consumption and age at menarche in a prospective study of US girls. Human Reproduction.

https://doi.org/10.1093/humrep/deu34 9

Curry, S. J., Krist, A. H., Owens, D. K., Barry, M. J., Caughey, A. B., Davidson, K. W., ... Wong, J. B. (2018). Screening for cervical cancer us preventive services task force recommendation statement. JAMA Journal of the American Medical Association.

https://doi.org/10.1001/jama.2018.108 97

D'Aloisio, A. A., Deroo, L. A., Baird, D. D., Weinberg, C. R., \& Sandler, D. P. (2013). Prenatal and infant exposures and age at menarche. Epidemiology. https://doi.org/10.1097/EDE.0b013e3 $1828062 \mathrm{~b} 7$

DeSantis, C., Ma, J., Bryan, L., \& Jemal, A. (2014). Breast cancer statistics, 2013. CA: A Cancer Journal for Clinicians. https://doi.org/10.3322/caac.21203

Editor, D. (2016). European Journal of Obstetrics \& Gynecology and Reproductive Biology. European Journal of Obstetrics and Gynecology. https://doi.org/10.1016/j.ejogrb.2008. 11.002

Elks, C. E., Perry, J. R. B., Sulem, P., 
Chasman, D. I., Franceschini, N., He, C., ... Murray, A. (2010). Thirty new loci for age at menarche identified by a meta-analysis of genome-wide association studies. Nature Genetics. https://doi.org/10.1038/ng.714

Ferlay, J., Steliarova-Foucher, E., LortetTieulent, J., Rosso, S., Coebergh, J. W. W., Comber, H., ... Bray, F. (2015). Reprint of: Cancer incidence and mortality patterns in Europe: Estimates for 40 countries in 2012. European Journal of Cancer. https://doi.org/10.1016/j.ejca.2015.05. 004

Getahun, F., Mazengia, F., Abuhay, M., \& Birhanu, Z. (2013). Comprehensive knowledge about cervical cancer is low among women in Northwest Ethiopia. BMC Cancer. https://doi.org/10.1186/1471-240713-2

Horvath, G., Chilo, J., \& Lindblad, T. (2010). Different volatile signals emitted by human ovarian carcinoma and healthy tissue. Future Oncology. https://doi.org/10.2217/fon. 10.60

Hsieh, C. - C, Trichopoulos, D., Katsouyanni, K., \& Yuasa, S. (1990). Age at menarche, age at menopause, height and obesity as risk factors for breast cancer: Associations and interactions in an international casecontrol study. International Journal of Cancer.

https://doi.org/10.1002/ijc.291046050 8

ICO, H., \& Centre, I. (2014). Human Papillomavirus and Related Diseases Report. HPV Centre.

Insanu, M., Anggadiredja, J., \& Kayser, O. (2012). Curcacycline A and B - New pharmacological insights to an old drug. International Journal of Applied Research in Natural Products.

K., O., S., Y., K., A., T., H., M., N., T., M., ... T., F. (2010). A case report of primary adenocarcinoma of small intestine. Japanese Journal of Cancer and Chemotherapy.
Lisnadiyanti, L. (2019). Hubungan Karakteristik Pasien Kanker Serviks Terhadap Dukungan Sosial Pada Pasien dengan Kanker Serviks di Ruang Rawat Inap di Rumah Sakit Kanker Dharmais. Journal of Health Science and Physiotherapy, 1(1), 3236.

https://doi.org/10.25311/hssh.v1i1.10

Marcom, P. K. (2017). Breast Cancer. In Genomic and Precision Medicine: Primary Care: Third Edition. https://doi.org/10.1016/B978-0-12800685-6.00010-2

Marmot, M. G., Altman, D. G., Cameron, D. A., Dewar, J. A., Thompson, S. G., \& Wilcox, M. (2013). The benefits and harms of breast cancer screening: An independent review. British Journal of Cancer. https://doi.org/10.1038/bjc.2013.177

Ndikom, C. M., \& Ofi, B. A. (2012). Awareness, perception and factors affecting utilization of cervical cancer screening services among women in Ibadan, Nigeria: A qualitative study. Reproductive Health. https://doi.org/10.1186/1742-4755-911

Parlagutan, M., Khairani, A., \& Simanjuntak, N. (2019). Studi Kasus Pemenuhan Kebutuhan Perfusi Jaringan Serebral Pasien Stroke Haemoragik di Rumah Sakit TK II Putri Hijau Medan Tahun 2018. Journal of Health Science and Physiotherapy, 1(1), 37-51. https://doi.org/10.25311/jhsp.v1i1.13

Perry, J. R., Day, F., Elks, C. E., Sulem, P., Thompson, D. J., Ferreira, T., ... Ong, K. K. (2014). Parent-of-origin-specific allelic associations among 106 genomic loci for age at menarche. Nature. https://doi.org/10.1038/nature13545 Sanajaoba Singh N, Sharat Singh N, , Narendra RK, U. (2010). 22.Online Journal of Health and Allied Sciences. Online Journal of Health and Allied Science. 
https://doi.org/10.1016/S0074-

6142(08)62813-2

Society, A. cancer. (2014). Cervical Cancer What is cancer? In American Cancer Society.

Sudenga, S. L., Rositch, A. F., Otieno, W. A., \& Smith, J. S. (2013). Knowledge, attitudes, practices, and perceived risk of cervical cancer among kenyan women brief report. International Journal of Gynecological Cancer. https://doi.org/10.1097/IGC.0b013e31 $828 \mathrm{e} 425 \mathrm{c}$

Zermeño-Nava, J. D. J., Martínez-Martínez, M. U., Rámirez-De-Ávila, A. L., Hernández-Arteaga, A. C., GarcíaValdivieso, M. G., Hernández-Cedillo, A., ... Navarro-Contreras, H. R. (2018). Determination of sialic acid in saliva by means of surface-enhanced Raman spectroscopy as a marker in adnexal mass patients: Ovarian cancer vs benign cases. Journal of Ovarian Research.

https://doi.org/10.1186/s13048-0180433-9 